\title{
Placing Borders in Development
}

\section{This is the pre-edit and pre-proofs $2^{\text {nd }}$ (accepted) submission of the article Novak P. (2016) Placing Borders in Development Geopolitics, online doi: 10.1080/14650045.2015.1118378}

\begin{abstract}
Development is inextricably related to the state-centred cartography of world spaces defined by borders, both in its historical trajectory and contemporary entanglements. Yet the multiplicity of channels and directions characterising their articulation are scarcely explored. This article contributes to this emerging field of enquiry. It delineates the essential traits of the borders and development nexus by establishing a systematic dialogue between the fields of Border Studies and Development Studies, a dialogue framed by concerns with scalar politics. More specifically, the paper places borders in development in two ways. First, it places borders in Development Studies: it identifies borders as a useful analytical vantage point that lay at the intersection between state- and non-state centred geographies of development. Second, it places Border Studies in development: focusing on the tension between borders and bordering processes, it interrogates economic growthand poverty-related policies. Three contributions to the study of development arising from placing borders in development in this way are highlighted. The paper also expands the emerging field of enquiry concerned with the relation between borders and development, by considering development policies not yet been examined through the prism of borders, and by emphasising the hierarchical and yet unpredictable nature of the borders and development articulation. At its broadest, the discussion dis-entangles the multiplicity of scales and directions in which borders, bordering and the development process intersect. It is at this scalar intersection that the force of development, and the potentials for engaging, opposing, avoiding, or subverting it, lay.
\end{abstract}

\section{Introduction}

Concerns with space and the spatiality of social relations emerged more than forty years ago at the margins of radical social theory, but are now de rigueur across the social sciences. Development Studies is no exception: contemporary academic work and policy-making documents use an extensive spatial imaginary and vocabulary, as they (more or less casually) deploy terms such as "horizontal and vertical" inequalities, cross-border "flows", "de-/re-territorialisation", or "de-/rebordering". In line with the objectives of this Special Issue, the following pages engage with these scalar concerns, as they investigate the complex spatiality of development though the prism of borders.

In particular, the paper delineates the essential traits of the borders and development nexus by establishing a systematic dialogue between the fields of Border Studies and Development Studies, a dialogue framed by a concern with scalar politics. In order to harness the potentialities offered by the intersection between these two fields, the following discussion places borders in development, in two ways. First, it places borders in Development Studies: that is, it examines contemporary development's discourses, policies and practices, to locate borders at the scalar intersection of development processes that unfold within as well as beyond and across states. Second, it places Border Studies in development: that is, it draws analytical insights and investigative perspectives from Border Studies to conceptualise this intersection, and uses them as analytical tools to interrogate development interventions. Placing borders in development in this way offers three contributions to the study of development. First, by re-interpreting disparate development policies as instances of border management interventions, it allows their interrogation from a single analytical vantage point. Second, it facilitates the identification of the multi-scalar and multi- 
directional social processes that shape such interventions and that are, at the same time, shaped by them. Third, it sharpens the study of development through the vast repertoire of questions and perspectives characterising the field of Border Studies.

Building upon the seminal work of Cowen and Shenton, this paper conceptualises development simultaneously across three dimensions: as an immanent process of politico-economic change; as an intentional project of amelioration led by international and other aid agencies; and as a set of social experiences and outcomes ${ }^{1}$. This conceptualisation of development is broader than the one typically used in existing contributions addressing the relation between borders and the development process. Thus, the paper also contributes to and expands this emerging field of critical enquiry, by considering development policies and interventions that have not yet been examined through the prism of borders, and by emphasising the hierarchical and yet unpredictable and fluid nature of the borders and development articulation.

The following sections develop these points and concerns. Next section delineates the essential traits of the nexus between borders and development, as a way of defining points of contact and departure from existing literature concerned with their relation. The following sections provide a focused and systematic treatment of relevant scalar debates in the fields of Development Studies and Border Studies, which facilitates the identification of cross-fertilisation lines. The first of these sections identifies state borders as an insightful analytical perspective for the study of development's spatiality. The following one defines such perspective using Border Studies literature and carves out prospective research agendas using two examples related to economic growth and poverty alleviation.

\section{Development at its borders}

Development is inextricably related to the state-centred cartography defined by borders. As an immanent, historical process of structural transformation, development shares with borders a colonial past, whose unequal premises and outcomes are constantly evoked and actualised by contemporary inequalities. Emerging out of European compulsions and imaginations ${ }^{2}$, the modern histories of borders and of development intersect and are rendered concrete in the age of Empires, when a colonial institution (borders), a colonial state project (development) and diverse populations, entangled in ways that continue to reverberate to this day ${ }^{3}$. Neither indigenous phenomena, nor foreign imports ${ }^{4}$, both development and borders have been key institutional sites of negotiation, contestation, cooption and cooperation weaving global, regional, national and local social forces and social groups, from colonial times to this day. Borders bring the past in the present, by carrying the sediments of long-term processes of state formation and state development ${ }^{5}$, and by continuously returning contemporary development interventions back to their colonial past, given the persistence of contradictions and inequalities originated during that historical moment ${ }^{6}$.

As an intentional project of amelioration, whereby projects, programmes and policies are implemented toward specific ends, development is deeply concerned with the functioning of borders. On one side, borders are seen as a bane for development. The political and economic success of developing countries is portrayed, in some contexts, as correlated to their size and shape, most often inherited at independence ${ }^{7}$. The incongruousness between borders and pre-colonial ethnic institutions ${ }^{8}$ is said to shape the configuration of governance institutions ${ }^{9}$, to hamper food security and agricultural production systems ${ }^{10}$, to facilitate smuggling ${ }^{11}$, and to increase the risk of secession $^{12}$. On the other side, borders are often posited as a resource for development and a solution to many development problems. The World Bank promotes the reduction of "divisions" between states, as "today's developing countries face a stark choice: stay divided and lose ground, or become winners without borders" ${ }^{13}$. In similar vein, regional ${ }^{14}$ and cross-border integration ${ }^{15}$ are promoted by policy-makers across the world as a panacea for economic development and security woes $^{16}$. Carefully managed borders are seen as crucial for harnessing the development potentials of 
migration and remittances ${ }^{17}$, and for "humanising" migration-management's ever-harsher controls ${ }^{18}$. Border management techniques, such as targeting and zoning, are also deployed in the realm of poverty alleviation to increase the efficiency and effectiveness of aid interventions.

As a set of experiences and outcomes, finally, development is inextricably related to borders, as the latter shape individual and social positions, opportunities and risks. At its broadest, nationality and place of birth define expected social development indicators ${ }^{19}$, the degree of civil liberties and the possibilities for democratic engagement in a national context, and the range of relevant legal frameworks available in the context of international migration. More directly, regional ${ }^{20}$ and global $^{21}$ migration circuits, and the ways in which borders' selective openings shape them, represent a source of livelihoods for millions of people across the world. So do border themselves, potentially, for most people living across, or caught up by, them, whether in relation to their economic and political strategies ${ }^{22}$, to development interventions in borderlands ${ }^{23}$, or to the evolution of border towns ${ }^{24}$.

Development and borders, in other words, articulate across a variety of spatial and temporal scales and, most importantly for the points developed here, in a multiplicity of directions across them. Studying development at its borders, thus, should offer valuable insights on the multi-scalar social forces shaping immanent processes of structural transformations and intentional development interventions; and on the ways in which borders and border management practices selectively and heterogeneously shape social experiences, positions and prospects, as they are being shaped by them. Surprisingly, however, only few studies attempt to discern in any systematic way the multiple social channels and spatial scales through which such relation unfolds ${ }^{25}$. What follows contributes to this emerging field of enquiry as it defines the borders and development nexus through a more complex conceptualisation of development than the one typically used in these contributions.

Indeed, these studies seem to frame their understanding of borders' articulation with development primarily by reference to development's immanent dimensions. They explain contemporary border transformations as flexible experimentations aimed at governing segments of the population and the national territory to accommodate global markets' imperatives ${ }^{26}$. They conceive regional border management arrangements as a "necessity for the global factory", albeit one that is articulated through multi-scalar state power projections, administrative spatial administrations and social regulations ${ }^{27}$. Most notably, they emphasise borders' complicity in joining, disconnecting, working together and working off practices of dispossession and exploitation, their "proliferation and transformation aimed at managing the creative destruction and constant recombining of spaces and times that lie at the heart of contemporary capitalism"28. In less erudite but equally poignant ways, they are concerned with the intersection between border controls, the violence of capitalism, precarious labour and systemic social hierarchies ${ }^{29}$.

These perspectives are crucial to capture the spatiality of the borders and development nexus, as they highlight its systemic significance and take great care in identifying the many scales through which the nexus reverberates. Yet, they limit their explanation of what drives and shapes its spatiality to the "agency and dynamics of capital and borders and their articulation with state projects at contrasting geographical scales" 30 -i.e. to its immanent dimension. This articulation is surely destabilised by "border struggles that take shape around the ever more unstable line between the inside and outside" 31 , and may well be decolonised by bringing to the fore "voices of colour" 32 , but ultimately responds to the workings of global capitalism. From the perspective of this paper, hence, these contributions are useful to capture the spatiality of development only "to a certain extent" $" 33$. Indeed, conceiving the spatiality of the borders and development nexus through a more complex definition of the development process, one that does not subsume development interventions under the imperatives of capital and/or the strategic responses of states, offers two contributions to this emerging field of critical scholarly enquiry. 
In relation to development's intentional dimension, first, such conceptualisation sets these imperatives and responses in relation to the broader range of concerns shaping development interventions, which go well beyond strategic responses to market imperatives or the need to mobilise labour, and which include (more or less genuine) concerns with poverty and social provisions, income-generation and livelihoods, democracy and governance. While at systemic level these fields of intervention are likely to be functional to the reproduction of global hegemonic forces and relations, the continuously changing logic motivating them, their heterogeneous operational mechanisms and their contextually diverse outcomes, defy any attempt at reductive interpretations. On one side, this expanded conceptualisation of development's intentional dimensions facilitates a more systematic dialogue between Border Studies and Development Studies literature as it does not assume or impose a definition of "what development is about" 34 , but rather acknowledges the various forces that shape and (mis-)guide development practitioners' and policy-makers' thoughts and interventions. On the other side, it expands the concerns of the abovedepicted emerging field of scholarly enquiry by considering development policies and interventions that have not yet been examined through the prism of borders, notably those related to the Good Governance and poverty alleviation agenda. By re-interpreting disparate development policies as instances of border management interventions, this approach allows their interrogation from a single analytical vantage point and thus sharpens and deepens the study of development through the vast repertoire of questions and perspectives characterising the field of Border Studies.

Second, conceiving the borders and development nexus through a more complex conceptualisation of the development process expands its significance beyond its being a "crystallisation of the tensions, conflicts, and struggles that invest the emerging articulations of the frontiers of capital and territorial borders" 35 . Rather, its sets this "crystallisation" in relation to the place-specific and mundane experiences and engagements that they generate, and that co-constitute its spatiality. It thus brings to the fore the unpredictable and fluid spatiality of contemporary border transformations. Borders and differences are of course always made, rather than given ${ }^{36}$, but they are not only made by the intertwining of cognitive and geographical borders and the axiomatic workings of capital ${ }^{37}$. On the contrary, they are subject to multiple negotiations, transgressions and re-appropriations, which can transform borders into a resource ${ }^{38}$ for those able to seize such benefits $^{39}$, which trace alternative geographies through localised trading practices ${ }^{40}$, and which reconfigure the subjective experience of localities ${ }^{41}$. These negotiations and transgressions are not only and not necessarily oppositional, destabilising or decolonising, and yet accommodate, transform, complicate and render uncertain the spatiality of the nexus ${ }^{42}$. Taking into account not only the immanent and intentional dimensions of development-related border interventions, but also the place-specific and fluid experiences, outcomes and engagements that they generate, foregrounds the dynamic and unpredictable everyday life of "fabrica mundi" 43 , historically" and in contemporary settings ${ }^{45}$. The spatiality of the borders and development nexus can only be captured through the investigation of its everyday manifestations.

Put differently, and as developed in the following sections, the conceptualisation of the borders and development nexus proposed here complicates, but at the same time renders more accurate, the identification of the multi-scalar and multi-directional social processes that define the spatiality of border interventions. Such conceptualisation does not conflate development interventions with their immanent dimension, whether this is seen in terms of developing countries submission to global corporations and non-market entities ${ }^{46}$, the imperatives generated by "the global factory" 47 , the "articulations that enable capital's circulation and support the expansion of its frontiers" 48 , or the tensions between the frontiers of capital accumulation and political-juridical boundaries ${ }^{49}$. Rather, while acknowledging the immanent significance of these social forces and social processes, it suggests that the actual spatiality of the borders and development nexus remains to be discovered through the examination of its concrete manifestations. An expanded conceptualisation of development, in sum, explains the systemic, pervasive and diffuse power of the borders and 
development nexus through an investigation of its heterogeneous, situated and experienced outcomes, rather than the other way around.

\section{Placing borders in Development Studies}

While during the golden age of development ${ }^{50}$, states and national economies were the primary if not exclusive socio-spatial unit of analytical concern, the broader "spatial turn" in social sciences, and its (lagging) circulation in the field of Development Studies, has increased awareness of the risks associated to "territorially trapped" assumptions about the economy, sovereign authority and society $^{51}$. State-centred analyses are problematic as it is only on the back of these assumptions that comparisons between, for example, developing countries' economic growth rates or governance indicators ${ }^{52}$ become meaningful. Even accepting such indicators and measurements as necessary abstractions that nevertheless provide synthetic information to guide development interventions, state-centred analyses offer, from this perspective, less accurate conceptualisations of the spatiality of development and explanations its uneven outcomes. As a result, an extensive spatial vocabulary has crept into most academic work and policy documents concerned with contemporary development dynamics. Even the World Bank has embraced such geographical imaginary. Its World Development Report of 2009 deploys and builds upon (its own understanding of ${ }^{53}$ ) terms such as scale, place, distance, and territory. This conceptual vocabulary reflects the perceived necessity to de-centre studies of development away from the state, privileging instead non-state centred scales of analysis and representation. Analytically, three different positions challenging state-centrism can be identified ${ }^{54}$.

Some scholars, first, see states as being hollowed out by processes occurring "above" and "below" them $^{55}$. They suggest that more accurate and significant explanations of development's spatiality and outcomes are to be found by emphasising donors' conditionalities and global governance frameworks, or, at the other end, political fragmentation along identity lines and kin-based institutions. In the words of Amin, "the post-1970s wave of globalisation has significantly decentred the role of the national scale as a self-enclosed container of socio-economic relations, such that we are witnessing a 're-scaling of territoriality' which includes the increased importance of both suband supranational forms of territorial organisation" ${ }^{56}$. Studies concerned with the overarching influence of donors on democratisation processes ${ }^{57}$, with the structuring force of global development architectures on the Global South ${ }^{58}$, or with the entanglement of neoliberal governance frameworks with kin-based territorial assemblages ${ }^{59}$, provide examples of this perspective. Other scholars, second, implicitly or explicitly posit the decreasing relevance of states in driving development processes and in shaping development outcomes by reference to "horizontal" and relational processes of connectivity. This is so, for example, in contributions taking transnational commodity chains $^{60}$ or development programmes ${ }^{61}$, and migration-, governance- or NGO networks $^{62}$, as the main analytical referent. Transnationality, networks and chains are often portrayed in these studies as possessing logics, causalities or mechanisms of coordination ${ }^{63}$ that cut across and somewhat transcend states and that, for this reason, more accurately represent the spatiality of development. Third, development scholars' ongoing attention to "the local", in relation to as diverse preoccupations as security ${ }^{64}$, livelihoods ${ }^{65}$, or the green economy ${ }^{66}$, to name a few, has traditionally contributed to the diffusion of situated and contextual scales of analysis and representation within Development Studies. From any of these perspectives, a focus on the national level as the primary unit of analysis and concern is seen as analytically problematic and inaccurate.

These analytical perspectives seem corroborated by transformations in development policies occurred over the same period, which have profoundly altered the spatiality of development interventions. Radical changes in the way in which economic growth and poverty alleviation prescriptions are now conceived and implemented lend support to the above contributions, as they seem to confirm development's re-scaling. Economic growth policies prescribe, since the 1980s, 
that integration into global markets is the only viable strategy for development, and strive to create regional and global economic spaces. Poverty alleviation strategies, similarly, have increasingly hollowed out autonomous state interventions, as they define their objectives based on universal aspirations and frameworks, and attempt to achieve them through localised and participatory interventions (these two sets of policies will be examined below).

The above analytical perspectives also seem to be confirmed by contemporary development's organisational modes and intervention practices. This is so, for example, in relation to so-called "global compacts", i.e. partnerships bringing together state- and non-state actors (governmental Ministries, UN Agencies, NGOs and private companies) for the implementation of development ${ }^{67}$ and humanitarian ${ }^{68}$ programmes. Each of these programmes, in turn, is designed, monitored and evaluated through networks, which foster transnational mechanisms of coordination and control ${ }^{69}$. Individual projects within such programmes, finally, are informed by spatially aware strategies concerned with "scaling up" or "scaling out" their implementation across and beyond the national territory $^{70}$. These modalities of intervention increasingly dilute governmental autonomy in the formulation and implementation of programmes and strategies.

In sum, contrary to the heydays of modernisation and dependency theories, when national economies or their subordinate position within the world system represented the main object of analysis and concern, the conceptualisation, organisation and implementation of contemporary development increasingly unfolds through global, local, and transnational scales, seemingly beyond and across states. From a mainstream point of view, non-state centred analyses highlight the opportunities and constraints offered by the interdependent and integrated context of globalisation, and recognise that national development problems cannot be solved exclusively by governments, but rather require multi-scalar partnerships. Furthermore, non-state centred policies improve the coordination and impact of aid, as they facilitate the targeting of, and responsiveness to, populations of concern, and suggest new ways of organising development programmes and projects. Critical scholars, in their many guises, use instead non-state centred analyses as a confirmation of the force of neoliberalism in driving development interventions ${ }^{71}$. They paint multi-scalar governance networks as mechanisms through which imperial formations are constituted and reproduced ${ }^{72}$. They portray non-state centred terrains as spaces of resistance and destabilisation of the development project $^{73}$.

In spite of all this, though perhaps unsurprisingly, many insist that the state remains the crucial development institution. This is so, from a mainstream point of view, whether we think about the way in which development policies are formulated: their aims (e.g. economic growth) and forms of institutional intervention (e.g. Poverty Reduction Strategy Papers) remain anchored to the national level. This is so, similarly, if we consider the way in which development goals (e.g. GDP growth) and indicators (e.g. Human Development Indexes) are set and measured. Critical scholars emphasise instead how state intervention is needed in order to carry out the reforms prescribed by the above policies. Indeed, many argue that the above policy transformations, rather than hollowing out the state, exemplify the use of state power to impose market imperatives across societies ${ }^{74}$. Variously depicted as potential enablers of or problems for development, states are, and have been so especially over the last thirty years, the primary site of development interventions ${ }^{75}$. Furthermore, integration into global markets or good governance frameworks do not seem a reality for the majority of populations, and states remain the main institutional realm for addressing political and economic grievances and claims, as they legislate and have obligations towards their citizens and under international legal frameworks. However permeable to global and transnational social processes, state institutions still decisively filter the flows of commodities, people and ideas unfolding across and beyond them, and states continue to be central vis-à-vis the specific ways in which global development interventions are defined and implemented. Put differently, while it is true that (mainstream or critical) development ideas, policies, institutions, encounters and exchanges, are intrinsically global and peculiarly contextual, they remain firmly anchored to state- 
centred (mainstream or critical) theorisations, aspirations, interventions, and data-collection methods.

It is at this scalar intersection that the analytical insights to be garnered by placing borders in Development Studies can be grasped. In particular, the above perspective seem to offer competing understandings of the most appropriate scale of analysis and representation for the study of development -alternatively emphasising the global and the structural, the relational and transversal, the national, or the situated and the place-specific. This is problematic, as suggested by Jessop, Brenner and $\mathrm{Jones}^{76}$, as the polymorphic, multidimensional character of sociospatial relations implies that no single dimension of sociospatial processes, scalar or otherwise, should be privileged.

What follows, thus, reframes these competing perspectives in terms of their "scalar politics"77, as it does not assume which of these scales is the most relevant one. Rather, it acknowledges the multiscalar sociospatial relations that co-constitute the spatiality of development, and suggests that the relative significance of each of these scales can only be captured through contextual analyses. From this perspective, borders seem an excellent vantage point, as this is where development processes that unfold within as well as across and beyond states intersect and entangle with each other -as they have done since colonial times. Borders are points of contact, division and articulation between various geographies of development. Gazing from such point ${ }^{78}$, the spatiality of development cannot be assumed a priori, but remains to be discovered. The following section seeks analytical insights and perspectives in the field of Border Studies to gaze the spatiality of development from this vantage point.

\section{Placing Borders Studies in development}

At its core, the field of Border Studies challenges rigid and static understandings of state-centred cartographies, promoting instead a more fluid conceptualisation of borders as dynamic social processes $^{79}$. "Fences and Neighbours in a Postmodern World" ${ }^{80}$ is the contribution that perhaps better than others represents the key analytical tenets characterising the field. Concisely, the article asserts that state boundaries are historically contingent human constructs, which appear, disappear and re-materialise. They are multi-dimensional as they involve not only territorial, but also symbolic, personal and discursive constructs. As such, they should be understood and studied through multicultural perspectives, whereby narratives emerging from societies that hold different representations of space and social identities are equally valued. Empirical studies are perhaps the best way of capturing these interactions. Contrasting the back-then hegemonic narrative that depicted globalisation as a homogenising and over-reaching set of processes, the article spawned a veritable "renaissance" of border studies ${ }^{81}$. This renaissance wanted to reinsert borders as one element of the discursive landscape of social power, control and governance, which extends itself into the whole society and which is produced and reproduced in various social and cultural practices $^{82}$. Despite the highly diverse disciplinary and conceptual aims characterising the field ${ }^{83}$, the numerous contributions that have given impetus to it since then have broadly been informed by such agenda. They have maintained important differences, however, especially in terms of which dynamic social process should be privileged in the study of borders.

Some scholars seem to be primarily concerned with processes that occur at or close to the border, and with the relation between borders and social identities. Seeing borders as a distinct spatial category that develops in relation to a multitude of social processes ${ }^{84}$, these contributions move away from linear and container-like conceptualisations of state-centred cartographies ${ }^{85}$, privileging instead the study of b/ordering processes. Social identities are not static, but rather the result of ongoing processes of differentiation and distinction (bordering), which simultaneously "order" and "other" 86 . Concerned with the multiplication of border forms, functions and practices and their distribution and proliferation in a variety of social and political arenas ${ }^{87}$, as opposed to lines and grids, prompts such literature to focus on the dispersed and fluid ways in which the dichotomies 
defined by borders unfold. These are likely to be different in different contexts, as they are made real or transgressed by those living near and across them.

Others have more recently taken issue with this "processual turn" ${ }^{88}$, suggesting instead that an excessive emphasis on dispersed agency, situated analyses and perspectivalism, may dissolve the distinctiveness of state borders in structuring social life. Expansive understandings enrich the field but they may obscure what a border "is" ${ }^{19}$. They may also overemphasise the novelty of contemporary border transformations, leaving to the background the inherited structures that enable, constrain or channel contemporary b/ordering processes ${ }^{90}$. Localised studies of the border may celebrate the agency of the "borderlander", but they may also underestimate the global reach of capitalism, patriarchy, and racism, which shape meanings, practices and relations in each borderland and assert their social force simultaneously across all borderlands ${ }^{91}$.

Since Fences and Neighbours, the field has broadly moved within the confines of these two approaches, either constructing knowledge about borders through situated and comparative analyses, or explaining borders on the bases of broader theories of social bordering. Even if some scholars posit these two positions as antithetic, and posing a dilemma that can only be solved through the demise of one or the other ${ }^{92}$, these perspectives do not need to be seen in such stark contrast $^{93}$. Indeed, recent scholarship offers tools that overcome such dichotomy, by offering new theorisations and concepts -such as borderscape ${ }^{94}$, networked border ${ }^{95}$, border multiple ${ }^{96}$, cosmopolitan border ${ }^{97}$, the border as "epistemic perspective" 98 - or by charting research agendas based on as wide a range of concerns as space/time ${ }^{99}$, place, performance and perspective ${ }^{100}$.

Building upon these contributions, this article locates the study of borders more firmly in relation to notions of scale and territory, for a number of reasons. First, many of these recent contributions do not appear to be much in conversation with one other, as they draw from diverse and often noncommunicating sets of literature. On the contrary, the relation between borders, territory and scale rests on a rich and established, however contested, field of study. It thus allows refining the use and understanding of consolidated language, questions and perspectives about borders, rather than offering new concepts and terminology, in an already overcrowded field. Many authors have suggested this as a useful line of investigation, albeit from contrasting positions ${ }^{101}$. Furthermore, this provides a common terrain that facilitates the identification of points of contact and crossfertilisation between the fields of Border Studies and Development Studies, as it allows a more systematic and disciplinary rigorous treatment of their relation ${ }^{102}$.

Second, studying borders from the perspective of scale allows to reframe the situated vs. structural positions discussed above through its prism. While all of the above scholars would in fact agree that borders are expressions of social relations and social practices, their conceptualisation and approach to the study of borders mostly privilege relations and practices unfolding at one or the other scale, alternatively emphasising situated and contextual processes of borderwork, or the global and structural forces and imperatives expressed and reproduced by borders ${ }^{103}$. Borders, however, simultaneously reverberate across all of these scales, as they interlink regions, places and networks ${ }^{104}$. They are, simultaneously, world-configuring institutions, functional devices that can be opened, closed and re-located, and heterogeneously experienced lines ${ }^{105}$. While borders attempt to shape space along state-centred scales of discourse and practice, the socio-spatial context providing the conditions for borders emergence, existence and transformations, is both situated and placespecific, and it extends across national, transnational, regional and global scales. Borders are the product of, and reproduce, social relations that unfold across both state- and non-state centred scales of discourse and practice; they express a scalar tension between their active and productive dimensions ${ }^{106}$. Conceiving borders in this fashion means that borders and b/ordering are not oppositional processes, but rather dimensions of the same relation; a scalar tension whose outcomes cannot be assumed a priori, but rather need to be investigated as they unfold in their actuality ${ }^{107}$. 
Third, thinking about borders and b/ordering processes not as an antinomy, but rather as a scalar tension allows to draw from the vast repertoire of questions and perspectives offered by the field of Border Studies -and to use them, in turn, to interrogate development. Much like those here, the scalar debates of concern to Development Studies discussed in the previous section, seem to revolve around the identification of the most accurate scale for the interpretation and representation of the spatiality of development. Some emphasise the global and the structural, looking at the influence of donors in shaping development policies across the world, or of governance networks in constituting transnational hegemonic compacts; others look instead for transnational connections cutting across states, whether related to industrial production, governance, trade or migration; others still study development by focusing on the local experiences and outcomes of development interventions. Many insist that the national level remains the most accurate and significant. Even those contributions that set the relation between borders and development across multiple scales, as discussed previously, ultimately seem to subsume their nexus to the workings of global capitalism, the need to mobilise labour, and the strategic responses of states.

Studying differently scaled, but simultaneous, spatialities of development as they actually intersect at the border, on the contrary, offers useful analytical insights on the heterogeneous ways in which these spatialities entangle with each other. More specifically, studying the borders and development nexus in this manner foregrounds its structuring yet fluid and dynamic reverberations across society; it accounts for multiple hierarchies and inequalities while remaining agnostic about the ways in which these configure themselves to produce experiences outcomes and engagements. The remainder of this section offers two examples, necessarily succinct for reasons of space, which illustrate the potentialities of placing Border Studies in development in this manner. They refer to policies that aim at increasing economic growth and at reducing poverty.

\section{Economic growth and (multi-scalar) integration}

The consolidation of neoliberalism as the dominant force in the field of development, at the beginning of the $1980 \mathrm{~s}$, brought to an end the belief that import-substitution industrialisation trajectories could set countries on the road to development, favouring instead export-oriented economic growth strategies ${ }^{108}$. Developing countries which until then were encouraged and supported by major development institutions, such as the World Bank and the IMF, to seek their own path to industrialisation through active interventions in the economy, asset ownership, planning exercises, tariffs, and regulations meant to protect infant industries, began to face a radically different set of recommendations ${ }^{109}$. On the back of a peculiar reading of East Asian countries' "success stories", those same institutions and donor states started promoting integration into world markets as the only viable alternative. Structural Adjustment Programmes forced developing countries to open up and integrate into the global economy by liberalising and deregulating their economies, by privatising national assets, by eliminating subsidies and tariffs. Government interventions came to be portrayed as market distortions, import tariffs as anathema, state-owned enterprises and banks, much like planning cycles, as corrupt and "political"110. According to this ideology, only markets are able to allocate resources efficiently, and they should thus be unleashed, if development is to be achieved. This belief has continued to define the development agenda ever since, constantly reiterated in various international statements and declarations, and further exacerbating these transformations. Clearly, this did not happen with the same intensity, pace and outcomes everywhere. Looking at these policies in light of the previous discussion it is possible to highlight three contributions that placing Border Studies in development can offer to capture these spatialities and explain these diverse outcomes.

First, the wide range of policies geared towards economic integration can be interpreted as instances of border management interventions. As suggested in a recent World Development Report, in fact, integrating national economies into world markets means that borders need to be thinned ${ }^{111}$. 
Borders are not problems in themselves, according to the World Bank; on the contrary, they enclose people with shared characteristics, provide a sense of place and belonging that contributes to social welfare, and generate manageable units for governing society ${ }^{112}$. Rather the "problem of borders" lays in their "width", i.e. the degree of restrictions that they impose to the free flow of trade, travel, and factors of production. Thinning the divisions created by borders can be achieved, as mentioned above, through multilateral institutional alignment, the reduction of tariffs and restrictions, the liberalization of capital markets and the establishment of new governance authorities and bodies. It also means transforming borders into bridges ${ }^{113}$, through the removal of physical barriers, the reduction of red tape, the (technological and human) improvement of custom facilities, and investment in infrastructure. These integration policies are promoted across the world, irrespectively of the specific conditions and trajectories of national economies, by all major donors $^{114}$. Similarly, de- and re-bordering strategies, whereby territorial jurisdictions are redefined in regional, cross-border and/or sub-national terms have also been aggressively promoted. The proliferation of Free Trade Agreements, Special Economic Zones, and Growth Corridors exemplifies these strategies. By creating territorial governance units among, across and within states, these political technologies, as Stuart Elden would call them ${ }^{115}$, are seen as fostering foreign direct investment, regional cooperation, and trade-led growth. The terms highlighted in italics above are familiar to Border Studies, and a first contribution that the field can offer to development is to provide a common analytical language and terminology to study disparate development policies from a single vantage point (see also poverty example below).

From this perspective, a second contribution refers to the increased attention to the social reverberations and imbrications of these policies across multiple scales that this vantage point opens up. The most accurate and significant scale for explaining transformations in the spatiality of development and its heterogeneous outcomes, in fact, seems to defy any attempt at reductive interpretations. States are clearly the primary drivers behind these transformations, albeit with different interests. The World Bank states that high-income countries such as the US or the EU promote these border management policies to support foreign policy goals, due to the slow progress in multilateral agendas, and as a way of gaining access to markets, fostering the intellectual property regime, and harmonising rules for investment. Developing countries, on the contrary, may pursue similar strategies to secure access to large markets, to attract Foreign Direct Investment, or as a framework for regional cooperation ${ }^{116}$. UNDP is more cautious and talks about fear of exclusion as the primary motivation for developing countries to enter into such arrangements ${ }^{117}$. Sohn ${ }^{118}$ These hierarchies also operate at regional level, with powerful states such as South Africa, Brazil or Thailand working as active promoters of regional integration strategies, despite the reluctance of some of their partners ${ }^{119}$.

At the same time, these state initiatives cannot be grasped without paying due attention to global political economy contexts. They confirm the overarching force of development donors and agencies, whether international such as the World Bank and IMF, or Regional ones, such as the UN Economic Commission for Africa and the Asian Development Bank ${ }^{120}$, in setting global development agendas. Their proliferation creates governmental assemblages that suit capitalist accumulation on a global scale, as they provide almost untrammelled market freedoms to powerful corporate interests, whether national or international, which can take advantage of the cost differentials and spatial fixes offered by these territorial units ${ }^{121}$. These units fragment space in ways that are functional to the articulation and grounding of global flows, as their aim is "not to eliminate differences but to work across them, to build passages and connections in an ever more fragmented world" ${ }^{\prime 22}$. These initiatives evidence, in other words, the all-encompassing force of neoliberalism in its attempt to establish markets' sovereignty across the world, and the immanent force of capitalist development in shaping processes of state development and transformation.

Yet, contextual and historically informed analyses are needed to capture the socio-spatial reverberations of these border interventions, as integration into markets, Economic Zones or growth 
corridors do not take the same form everywhere, nor do they produce the same outcome in all places and for every individual and social group. While they may well function as a "crystallisation of the tensions, conflicts, and struggles that invest the emerging articulations of the frontiers of capital and territorial borders" ${ }^{\prime 23}$, their spatiality cannot exclusively be explained by reference to their functions in contemporary capitalism.

The actual spatiality and outcomes of these policies, for instance, needs to be set against preexisting and changing patterns of migration, and the ways in which they are affected by, reify, or subvert, these territorial re-configurations ${ }^{124}$. Their actual territorial shape cannot be explained without accounting for the ways in which land brokers or landowners mediate, co-opt, or resist such initiatives $^{125}$. Their subjective meanings and significance are further modified by the cultural logics that re-interpret their symbolic content, whether this is done by transnational elites' construction and strategic deployment of fluid social identities ${ }^{126}$, or by small-traders' (re)negotiation of their connections to power-holders within networks of production ${ }^{127}$. The extent of these transformations' novelty, finally, needs to be inserted in long-term processes of state development and transformations that, since colonial times, have shaped the continuously changing social and territorial location of borders across the world. In Southern Africa, for example, long-term processes of formal institutional integration began with colonial powers' labour exchanges ${ }^{128}$, while informal processes of integration ${ }^{129}$ and identity construction ${ }^{130}$, have, since then, continuously shaped border management practices, as they were being shaped by them. In South East Asia, since colonial times borders have functioned as mechanisms for the regulation of labour migration flows $^{131}$, and much as they bend and are stretched in response to global economic imperatives ${ }^{132}$, their significance needs to be set in relation to long term patterns of regional migration. Similar considerations can be made for other regional contexts, whether in South America ${ }^{133}$ or elsewhere.

Indeed, borders are dynamic social processes that spread across the whole of society ${ }^{134}$, and their management is in turn renegotiated, transformed and reappropriated by a variety of agents operating across multiple scales. They bring the past in the present ${ }^{135}$, the continuation of structural and longterm processes of state transformation. Neither indigenous phenomena nor foreign imports, they are the dynamic result of complex borderwork practices that operate across multiple scales ${ }^{136}$, which can only be captured as they unfold in their actuality. If the objective is to capture the spatiality of development and to explain heterogeneous development outcomes more accurately, then, the significance of the above border management practices should be assessed across the manifold scales and the multiplicity of directions that are affected by, and in turn affect, such policies and practices. The third contribution that the field of Border Studies can offer to the study of development refers precisely to the vast repertoire of questions and perspectives that facilitate this effort.

\section{Poverty and Good (multi-scalar) Governance}

Ever since the consolidation of development as an intentional project of societal amelioration, poverty and its alleviation/eradication have prominently featured as one of its key concerns and objectives. Over the decades, however, the way in which poverty alleviation policies have been conceptualised and implemented has varied enormously. Much like in the previous example, the neoliberal turn profoundly altered the rationale, role and functions of governmental action in poverty-related interventions. In particular, policies associated to the above-mentioned Structural Adjustment Programs implied a reduction, if not an altogether withdrawal, from anti-poverty spending, and a move from universal to targeted provisions. It also involved the establishment of market mechanisms in service delivery sectors such as health and education, through the introduction of user fees, the privatisation of service providers and an increased competition through the involvement of NGOs and private companies ${ }^{137}$. Market-based development strategies, in other words, are not only all pervasive in relation to growth-related concerns, but they also 
became the norm in the context of poverty alleviation. Much like in the previous example, placing Border Studies in relation to poverty alleviation policies allows interrogating these policies from a common analytical vantage point, capturing the diverse scales and directions through which these policies reverberate, and deploying a vast repertoire of question to interrogate them, all of which facilitates the accurate identification of development's spatiality.

First, the wide range of policies and institutional transformations developed and promoted to guide and transform poverty eradication strategies, the so-called "Good Governance Agenda"138, may be seen as instances of border management interventions. This is not so much in relation to the degree of openness/closure of borders to trade and financial flows, as in the previous example -although the global spread of these ideas testifies the extent of national borders' permeability to global development discourses. Rather, the move from universal to targeted provisions implies a redefinition beyond the national level of the social groups and geographical areas that "benefit" from poverty interventions. Targeting, understood as a mechanism used for identifying eligible individuals and screening out ineligible ones for the purposes of transferring resources ${ }^{139}$, can effectively be considered a bordering exercise. Concerned with the management of territory and populations, targeting is a socio-spatial strategy that includes/excludes, identifies and differentiates populations and areas according to the above-spelled narratives and discourses. It involves $d e-$ and re-bordering processes, as in the case of the decentralisation of service provisions and the redefinition of the functions and responsibilities of sub-national jurisdictions ${ }^{140}$. It is also concerned with mapping poverty in ways that go beyond existing administrative boundaries, for instance through zoning territories based on their food economy ${ }^{141}$. It attributes agency for development to "communities" or households, understood as coherent units of people who inhabit bounded geographic spaces ${ }^{142}$. Targeting is an (b)ordering force ${ }^{143}$ that identifies specific populations (e.g. the poorest of the poor), or places (e.g. lagging areas) as objects of differential treatment on the part of governments and development agencies. The WDR 2009 warns, for instance, against "spatially blind" interventions, favouring instead the identification of lagging areas for more efficient poverty reduction transfers ${ }^{144}$. Targeting women's economic empowerment is seen as having more lasting effects on their status than national gender action plans ${ }^{145}$. Targeting youth, orphans, children or marginalised ethnic groups may increase the effectiveness of development projects ${ }^{146}$. The inchoate process of bounding associated to targeting exercises, marks off categories as distinct by creating imaginary lines, produces the perception of difference, and in turn shapes, organises and controls everyday life ${ }^{147}$. From this perspective, and much like in the previous example, interrogating poverty alleviation strategies through the prism of Borders Studies facilitates the analysis of disparate development concerns from a single analytical vantage point.

Second, it also increases awareness of the multiple scales through which these policies reverberate and with which they are imbricated; scales and spatialities that defy any simple state/non-state or global/local dichotomy. While the poverty alleviation agenda has been couched in terms of developing countries' "ownership" of such policies, following the recognition by the IMF and the World Bank of the importance of governmental leadership for effective poverty reduction exercises $^{148}$, in fact, the agenda is informed by narratives and discourses that place a great emphasis on levels "above" and "below" the state. National development objectives are defined by reference to "universal" aspirations, such as those formulated in the Millennium Development Goals, and to "international" concerns framed around Human Rights, democratisation, or more recently, security. At the same time, its implementation is prescribed through modalities of intervention that aim to bring the state closer to the people, to make it more responsive to local demands, to empower communities, etc. Administrative decentralisation, accountability and participation, are keywords of development interventions to this day, which make "the local" a crucial realm for the unfolding of development interventions and for explaining their outcomes.

The twin imperatives of integration into global governance frameworks and of responsiveness to local communities, seemingly hollow out governmental action, as they effectively restrict practical 
and political options ${ }^{149}$. Indeed, many argue that ownership and participation are simply cosmetic processes $^{150}$, an articulation of US-led imperialism and its neoliberal agenda ${ }^{151}$. From a postdevelopmental perspective, poverty narratives and policies are seen instead as mechanisms of control that are just as pervasive and effective as those deployed during colonial times ${ }^{152}$. More cautiously, yet equally incisively, others believe that this agenda does express a genuine concern for poverty alleviation, but see the latter as premised on the idea that developing countries' societies need to be transformed to foster and support capitalist imperatives ${ }^{153}$. Certainly, the Good Governance agenda seemingly transcend states, as it effectively brings into direct contact the "international" and the "beneficiary" communities ${ }^{154}$.

As in the previous example, however, the diversity in the pace, intensity and outcomes of poverty alleviation strategies, suggests that this is not a unidirectional process, but that it rather needs to be inserted in wider spatial and temporal scales. Governments have been eager implementer of such agenda, whether enticed or compelled by the prospects of accessing loans through its adherence. Dialogue and cooperation between governments and financial institutions in poverty-related matters differs amongst countries based on domestic political interests ${ }^{155}$, as "political settlements" seem to be better predictors of effective societal transformations than governance indicators ${ }^{156}$. Within each country, furthermore, interactions between, and the relative force of, the different Ministries and civil servants involved in implementing good governance reforms shapes the commitment to such reforms beyond the formal level ${ }^{157}$. It is also affected by politics of patronage ${ }^{158}$.

Finally and importantly, while the specific outcomes of poverty alleviation policies are structured by long-term accumulation and state development strategies, they are also rendered unpredictable by the multiple situated re-appropriations and transgressions enabled by such policies. The significance and subjective experience of terms such as "community", "household" or, indeed, "poverty" are always subject to the dynamic and ongoing processes of re-interpretation, cooperation and cooption, and re-appropriation by those individuals and social groups invested by them ${ }^{159}$. Their spatiality stretches and extends through the social spaces established between such "communities" and transnational migrants belonging to them ${ }^{160}$, or politically intervening in their decision-making processes ${ }^{161}$. Once again, the most accurate and significant scale for explaining development's spatial transformation and its heterogeneous outcomes seems to defy any attempt at reductive interpretations.

Third and much like in the previous example, recognising the multi-directional articulation of development interventions across scales, suggests a conceptualisation of their spatiality that is certainly more complex, but that also seems more accurate; it prevents from subsuming povertyrelated initiatives such as targeting and zoning under the heading "market-driven calculations introduced in the management of territory and populations" $" 162$. On the contrary, interrogating these policies through the vast repertoire of questions available within Border Studies forces us to capture the intersection between borders and bordering processes as it manifests itself in its actuality. This is not simply about providing nuance to structural accounts of development through perspectival and situated analysis, or inserting the latter in long-term processes of structural transformations. Rather, if we accept that these policies, much like borders, are dynamic social processes that spread across the whole of society, studying them as they unfold in their actuality forces us to investigate, rather than assume, the heterogeneous significance of development's scalar configurations, and the heterogeneous opportunities that the latter selectively open up for transgressions, cooption, cooperation, and re-appropriations, beyond oppositional, destabilising or decolonial struggles, and that transform the spatiality of the border and development nexus.

\section{Borders, bordering and development}

Perhaps with some anticipation vis-à-vis similar soul-searching exercises in Border Studies, the field of Development entered its theoretical "impasse" in the middle of the $1980 \mathrm{~s}^{163}$, when existing 
theories came to be challenged by a series of critiques that seemingly undermined its edifice. Whether framed around feminist, post- or alternative development concerns, these critiques substantially questioned the positivist and linear understanding of development as a process unfolding over time within states, dominant in both neoclassical economics and (post)Marxist variants. The dominance of neoliberal ideas in the field, as much as the overarching force of major development Agencies and donor states, has further exacerbated this impasse, by co-opting some critiques into "inclusive liberalism" narratives and by eradicating any possibility of conceiving radical critiques that are in conversation with the mainstream. Indeed, Development Studies scholarship seems characterised by profound methodological divisions, which are pitted in oppositional and zero-sum terms, divisions that are reproduced through academic institutions and through scholars' interpellation of mostly captive audiences in equally divided conferences and publication outlets - divisions that neoliberal forces within academia are only eager to exploit, and successfully have done so thus far ${ }^{164}$.

Attempting not to fall into this trap, but rather harnessing the synergies that the engagement with multiple sets of scholarly work may produce, the above pages have attempted to subvert the boundaries sustaining self-referential and often non-communicating communities, by reframing their epistemological battles in scalar terms, i.e. by conceiving their different methodological emphases as instances of a "politics of scale" debate ${ }^{165}$. This means that rather than explaining the process of production of space associated to the borders and development nexus through structural processes of capitalist development, through transnational and relational networks and connections, through the articulations of cognitive and material boundaries and the axiomatic workings of capital, or through the place-specific examination of subjective experiences and perceptions, the above analysis suggests that the spatiality of this nexus needs to be discovered as it manifests itself in its actuality. Put differently, while acknowledging the relevance of each of these differently scaled processes in co-constituting the spatiality of development, each being the expression of a peculiar set of social relations, the article has rejected any pre-supposition in respect to the ways in which these relations configure themselves in context, and to their situated social and subjective implications. This is because, while acknowledging the immanent significance of long-term, processes of capitalist development, of patriarchy and of racism, to name a few, and their allpervasive force in shaping development's intentional projects of societal amelioration and development's social experiences and outcomes, their situated configuration and outcomes are fluid, nuanced and selectively enabling. Development's spatiality cannot be assumed a priori but needs to be discovered.

In this respect, the field of Border Studies offers useful insights and analytical tools to investigate development's spatiality. In particular, as argued above, placing borders in development allows, first, the study of disparate development policies and practices as instances of border management interventions aimed at managing populations and territories according to the (b)ordering force that generates them. Second, it facilitates capturing the multiple scales through which this force reverberates and the negotiated, re-appropriated and transgressed nature of its outcomes, which in turn alter, transform and render unpredictable its spatiality. The vast repertoire of questions that can be drawn from the field of Border Studies, third, provides useful research avenues in this respect.

Deploying a more complex conceptualisation of development, the above pages have also contributed to, and expanded, the emerging field of critical scholarly enquiry concerned with the relation between borders and development, delineating the essential traits of the nexus articulating them. In particular, the above pages attempted to expand the range of development policies that can be examined through the prism of borders, and to complicate the understanding of the spatiality of this nexus by considering the unpredictability and fluidity of its manifestations. This approach does not redefine borders what borders "are" and "do" on the basis of their networked or scaped proliferation and heterogenisation. On the contrary, by considering borders and bordering as instances of the same process, it not only brings to the fore their vacillations and relocations, but 
also the inescapable materiality of their linear inscription, which is constitutive of the state-centred cartography through which development unfolds. This seems important analytically, as discussed above, but also politically as it suggests, in ways that cannot be explored here, that the national scale is still an important realm for addressing progressive politics.

Borders are dynamic social processes that heterogeneously spread across society, the result of longterm processes of state development and state formation that are constantly negotiated and subverted in their spatiality. Borders and bordering processes are not opposing perspectives, but rather dimensions of the same process. It is precisely at the scalar intersection between borders, understood as linear markers of territorial jurisdictions, and bordering, understood as fluid, situated and dynamic social process, that the force of development, and the potentials for opposing, avoiding, or subverting it, lay.

\footnotetext{
${ }^{1}$ I conceptualise development using Cowen and Shenton's distinction between immanent and intentional dimensions of development. M. Cowen and R. Shenton, Doctrines of Development (London: Routledge, 1996); M. Cowen and R. Shenton, 'The Invention of Development' in J Crush (ed), Power of Development (Routledge 1995), pp. 27-43. For more policy-oriented understandings of this definition and distinction, see also D. Mitlin, S Hickey, A._Bebbington 'Reclaiming Development? NGOs and the Challenge of Alternatives' World Development 35/10(2007), 1699-1720; and S. Hickey, and G. Mohan 'Relocating participation within a radical politics of development' Development and Change, $200536(2)$, pp. 237-262. I add to these two dimensions a third one, the experience of development.

${ }^{2}$ See Cowen and Shenton, note 1; A B Murphy 'Territory's Continuing Allure' Annals of the Association of American Geographers 103 (2013), 1212-1226; J. Anderson, 'Borders in the New Imperialism' in T. Wilson and H. Donnan (eds), Wiley-Blackwell Companions to Anthropology, Volume 26: Companion to Border Studies. (Chichester: WileyBlackwell, 2012), Ch. 8, 139-157

${ }^{3}$ F. Cooper, 'The Recurrent Crises of the Gatekeeper State' in his Africa since 1940. The Past of the Present, Cambridge CUP 2002, Ch 7 pp. 156-190

${ }^{4}$ ibid; see also P. Novak 'The Flexible Territoriality of Borders' Geopolitics 16/4(2011), pp. 741-767; W. Zeller, 'Neither Arbitrary nor Artificial: Chiefs and the Making of the Namibia-Zambia Borderland' Journal of Borderlands Studies, 25/ 2 (2010), pp. 6-21; R. Connell and D. Nour, 'Where in the world does neoliberalism come from?' Theory and Society 43/2 (2014), pp 117-138. These accounts deploy a much more nuanced and contextual understanding of borders' demarcations and of development, to account for the contestations, re-appropriations and cooption of multiple agents. See also below in this section.

5 L. O’Dowd, "From a 'borderless world' to a 'world of borders': 'bringing history back in'" Environment and Planning D: Society and Space 28/6 (2010), pp. 1031 - 1050

${ }^{6}$ P. Scott-Villiers, 'We Are Not Poor! Dominant and Subaltern Discourses Of Pastoralist Development in The Horn Of Africa' Journal of International Development, 23(2011): 771-781; R. Kiely 'Imperialism or globalisation? ... Or imperialism and globalisation: Theorising the international after Rosenberg's post-mortem' Journal of International Relations and Development 17/2(2014), 274-300

${ }^{7}$ see E. Green, 'On the Size and Shape of African States' International Studies Quarterly, 56(2012): 229-244; A.

Alesina, W. Easterly, and J. Matuszeski 'Artificial States' Journal of the European Economic Association, 9/2(2011), pages 246-277; for contrasting views

${ }^{8}$ S. Michalopoulos and E. Papaioannou, 'Pre-Colonial Ethnic Institutions and Contemporary African Development' Econometrica, 81(2013): 113-152

${ }^{9}$ C.O. Bassey; O. Oshita, Governance and Border Security in Africa (African Books Collective, 2010).

${ }^{10}$ S. Haggblade, 'Unscrambling Africa: Regional Requirements for Achieving Food Security' Development Policy Review, 31(2013): 149-176

${ }^{11}$ JC. Aguiar, 'Cities on edge: Smuggling and neoliberal policies at the Iguazú triangle' Singapore Journal of Tropical Geography 33/2 (2012), pages 171-183

${ }^{12}$ M. Larmer and E. Kennes, 'Rethinking the Katangese Secession (co-authored with Erik Kennes)' . Journal of Imperial and Commonwealth History (2014) , 1-21

${ }^{13}$ World Development Report 2009. Reshaping Economic Geography (Washington, World Bank, 2009): p. 262
} 
${ }^{14}$ ECA, 2004. "Opportunity and Necessity" in Assessing Regional Integration in Africa (Addis Abeba: ECA World Bank, 2009). See also Sohn, note 15, different take, suggesting that borders do not become a resource simply through their removal, but only through the active engagement with them of agents able to size such opportunities.

${ }^{15}$ C. Sohn, 'Modelling Cross-Border Integration: The Role of Borders as a Resource' Geopolitics 19/ 3 (2014), pp. $587-$ 608

${ }^{16}$ D. Suba Chandran, P.G. Rajamohan 'Soft, Porous or Rigid? Towards Stable Borders in South Asia' South Asian Survey 14/1 (2007): pp. 117-128

${ }^{17}$ J. Cortina and E. Ochoa-Reza New Perspectives on International Migration and Development (New York: Columbia University Press 2013)

${ }^{18}$ A. Mountz \& J.M. Loyd 'Constructing the Mediterranean region: Obscuring violence in the bordering of Europe's migration 'crises", ACME: An International E-Journal for Critical Geographies 13/2(2014): pp 173-195

${ }^{19}$ E.R. Pamuk, R. Fuchs, and W. Lutz, W. 'Comparing Relative Effects of Education and Economic Resources on Infant Mortality in Developing Countries' Population and Development Review, 37(2011): 637-664

${ }^{20}$ A. Kaur A. and I. Metcalfe I. (eds.), Mobility, Labour Migration and Border Controls in Asia. (New York: Palgrave, 2011)

${ }^{21}$ Cortina and Ochoa-Reza note 17

${ }^{22}$ D. Feyissa D and MV. Hoene "State Borders and Borderlands as resources" in Feyissa and Hoene (eds) Borders and Borderlands as Resources in the Horn of Africa (London: James Currey, 2010), Ch.1 pp. 1-26

${ }^{23}$ J.C Sturgeon, "Border Practices, Boundaries, and the Control of Resource Access: A Case from China, Thailand and Burma" Development and Change 35/3(2004): 463-484

${ }^{24} \mathrm{P}$. Nugent 'Border Towns and Cities in Comparative Perspective' in T Wilson and D Hastings (eds) Wiley-Blackwell

Companions to Anthropology, Volume 26 : Companion to Border Studies (Hoboken, NJ, USA: Wiley-Blackwell,

2012); G Dobler 'From Scotch Whisky to Chinese Sneakers: International Commodity Flows And New Trade Networks in Oshikango, Namibia' Africa 78/3(2008): 410-432

${ }^{25}$ While various references appear throughout the text, the most significant ones in this respect, and the ones discussed here more in detail are: A. Ong, 'Graduated sovereignty' Theory, Culture \& Society 17/4 (2000) pp. 55-75; D. Arnold, D. and J. Pickles 'Global Work, Surplus Labor, and the Precarious Economies of the Border' Antipode, 43(2011) pp. 1598-1624; S. Mezzadra and B. Neilson Border As Method, or, the Multiplication of Labor (Durham, NC, USA: Duke University Press, 2013); A. Smith 'Macro-regional integration, the frontiers of capital and the externalisation of economic governance' Transactions of the Institute of British Geographers early view (2015).

${ }^{26}$ Ong, note 25

${ }^{27}$ Arnold et al., note 25

${ }^{28}$ Mezzadra and Neilson, note 25, p. 344 and 6 respectively.

${ }^{29}$ H. Walia Undoing Border Imperialism (Washington DC: AK Press / Institute for Anarchist Studies, 2012)

${ }^{30}$ Smith note 25

${ }^{31}$ Mezzadra and Neilson, note 25, p.13

${ }^{32}$ Walia, note 29

${ }^{33}$ Novak, note 4

${ }^{34}$ See D. Booth 'Marxism and Development Sociology: Interpreting the Impasse' World Development 13/7(1985), 761787; F Schuurman Beyond the Impasse: new directions in development theory (London. Zed Books, 1993), and the last section

${ }^{35}$ Mezzadra and Neilson, note 25, p. 242

${ }^{36}$ Ibid, p.64

${ }^{37}$ Ibid. p. 59

${ }^{38}$ D. Feyissa and M. Hoene (eds) Borders and Borderlands as Resources in the Horn of Africa (London: James Currey, 2010)

${ }^{39}$ Sohn, note 15

${ }^{40}$ T. Harris, "Trading places: New Economic Geographies of Trade Across Himalayan Borderlands," Political Geography 35 (2013), pp. 60-68

${ }^{41}$ A. Benz (2014) 'Multilocality as an Asset. Translocal Development and Change among the Wakhi of Gojal' in H. Alff and A. Benz (eds.) Tracing Connections - Explorations of Spaces and Places in Asian Contexts (VWB: Berlin, 2014), pp. 111-138.

${ }^{42}$ Smith, note 25, similarly “extends Mezzadra and Neilson's framework to an understanding of the agency and dynamics of capital and borders and their articulation with state projects" by recognising that state projects, rather than the state as a political-juridical formation, are reconfiguring this relationship in fundamental ways. While similarly concerned with the nexus' immanent dimension, he also points to its negotiated, dynamic and unpredictable character.

${ }^{43}$ Mezzadra and Neilson, note 25, Ch.2

${ }^{44}$ See note 4 above

${ }^{45}$ See 'economic growth' and 'good governance' examples in the following sections

${ }^{46}$ Ong note 25 
${ }^{47}$ Arnold et al. note 25

${ }^{48}$ Mezzadra and Neilson note 25

${ }^{49}$ Smith note 25

${ }^{50}$ A. Payne and N. Phillips Development (Cambridge: Polity Press, 2010)

${ }^{51}$ J.A. Agnew and S. Corbridge, Mastering Space: Hegemony, Territory and International Political Economy (London: Routledge, 1995)

52 see, as an example, how the World Bank compiles country indicators for economic performance (http://data.worldbank.org/indicator/NY.GDP.MKTP.CD?page=5) and governance (http://info.worldbank.org/governance/wgi/index.aspx\#home)

${ }^{53}$ See the useful critique of J. Peck and E. Sheppard 'Worlds Apart? Engaging with the World Development Report 2009: Reshaping Economic Geography' Economic Geography 86/4 (2010), pp. 331-340

${ }^{54}$ P. Novak, 'Tracing connections and its politics' in H. Alff and A. Benz (eds.) Tracing Connections - Explorations of Spaces and Places in Asian Contexts (VWB: Berlin, 2014) pp. 21-40

${ }^{55}$ N. Brenner, 'Beyond state-centrism? Space, territoriality, and geographical scale in globalization studies', Theory and Society_28/1(1999): 39-78

${ }^{56}$ A. Amin, 'Spatialities of Globalisation', Environment and Planning A 34/3 (2002) p. 387

${ }^{57}$ J. Kamstra, L. Schulpen 'Worlds Apart But Much Alike: Donor Funding and the Homogenization of NGOs in Ghana and Indonesia Studies' in Comparative International Development (2014) online first, http://link.springer.com/article/10.1007/s12116-014-9169-8 accessed 15 March 2015

${ }^{58}$ S. Kamat "The New Development Architecture and the Post- Political in the Global South" in Japhy Wilson and Erik Swyngedouw (eds) The Post-Political and Its Discontents. Spaces of Depoliticisation, Spectres of Radical Politics (Edinburgh: Edinburgh University Press, 2014), Chapter 4: 67-84

${ }^{59}$ D. J. Murphy 'Ecology of Rule: Territorial Assemblages and Environmental Governance in Rural Mongolia' Anthropological Quarterly 87/3 (2014), pp. 759-792

${ }^{60}$ A. Mezzadri 'Globalisation, informalisation and the state in the Indian garment industry.' International Review of Sociology 20/3 (20103) pp. 491-511

${ }^{61}$ S. Sinha 'Lineages of the Developmentalist State: Transnationality and Village India, 1900-1965' Comparative Studies in Society and History 50/1 (2008): pp 57-90

${ }^{62}$ M. Duffield 'Development, Territories, and People: Consolidating the External Sovereign Frontier' Alternatives: Global, Local, Political, 32(2007), pp. 225-246.

${ }^{63}$ H. Leitner, C. Pavlik, and E. Sheppard, 'Networks, Governance, and the Politics of Scale: Inter-Urban Networks and the European Union', in A. Herod and M. W. Wright (eds.), Geographies of Power: Placing Scale (Oxford: Blackwell 2004) pp. 274-303

${ }^{64}$ R. Mac Ginty, G. Sanghera 'Hybridity in Peacebuilding and Development: an Introduction' Journal of Peacebuilding \& Development 7/2(2012), pp. 3-8

${ }^{65}$ A. Ulrich 'Export-Oriented Horticultural Production in Laikipia, Kenya: Assessing the Implications for Rural Livelihoods' Sustainability 2014, 6(1), 336-347

${ }^{66}$ N. Gregson, M. Crang, Mike, J. Botticello, M. Calestani, and A. Krzywoszynska 'Doing the 'dirty work' of the green economy : resource recovery and migrant labour in the EU.' European Urban and Regional Studies , (2014) online first http://eur.sagepub.com/content/early/2014/10/29/0969776414554489.abstract accessed 15/3/2015

${ }^{67}$ I. Smillie, H. Helmich, T. German, J. Randel Stakeholders: Government-NGO partnerships for international development. (Paris, France: Organisation for Economic Co-operation and Development, 1999)

${ }^{68}$ P. Tatham, M. Christopher Humanitarian logistics: Meeting the challenge of preparing for and responding to disasters (London: Kogan Page, 2014)

${ }^{69}$ See Save the Children webpage http://designmonitoringevaluation.blogspot.co.uk/2010_03_01_archive.html accessed 18 March 2014

${ }^{70}$ See for example T. Boudreau 'Mozambique: Food Economy Baseline Profile of the Lower Limpopo Food Economy Zone: Gaza Province, Mozambique' FEG Reports (2001) Available http://www.fegconsulting.com/resource/reports/lowerLimpopoBaseline.pdf/view?searchterm=None accessed 18 March 2014

${ }^{71}$ J. Peck 'Explaining (with) Neoliberalism' Territory, Politics, Governance 1/2(2013), 132-157

${ }^{72}$ Duffield note 37, P. Novak 'The Institutional Incompleteness of Empire' Central Asian Survey, 30/3-4(2011): pp. 389406.

${ }^{73}$ A. Escobar Territories of Difference: Place, Movements, Life, Redes (Durham, NC: Duke University Press, 2008)

${ }^{74}$ A. Saad Filho and D. Johnston (eds) Neoliberalism: A Critical Reader (London: Pluto Press, 2004)

${ }^{75}$ L. Pradella Globalization and the Critique of Political Economy: New Insights from Marx's Writings (Routledge Frontiers of Political Economy, 2015)

${ }^{76}$ B. Jessop, N. Brenner, M. Jones 'Theorizing sociospatial relations' Environment and Planning D: Society and Space 26/3(2008): $389-401$

77 This debate has taken different shapes and directions over the years; see for example N. Smith 'Geography, difference and the politics of scale' in J. Doherty E. Graham M. Malek, M. (Eds) Postmodernism and the social sciences (London: 
Macmillian, 1992) pp. 57-59; E. Swyngedouw 'Neither global nor local: 'Glocalization' and the politics of scale' in Cox, K. (Ed), Spaces of globalization: Reasserting the power of the local (New York, NY, US: Guilford, 1997): pp. 137-166; S Marston 'The social construction of scale' Progress in Human Geography 24/2(2000): 219-242. More recent, and applied, contributions are E.S Norman K. Bakker and C. Cook 'Introduction to the themed section: Water governance and the politics of scale' Water Alternatives 5/1(2012): 52-61; M. Bastos Lima and J. Gupta 'Extraterritorial Dimensions of Biofuel Policies and the Politics of Scale : Live and Let Die?' Third World Quarterly 35/3(2012): 392-410

78 cf. C Rumford, 'Seeing like a border' Political Geography, vol 30, no. 2, 2011

${ }^{79}$ A. Paasi, 'Boundaries as Social Processes: Territoriality in the World of Flows', Geopolitics 3/1 (1999) pp. 69-88

${ }^{80}$ D. Newman and A. Paasi, 'Fences and Neighbours in the Post-Modern World: Boundary Narratives in Political Geography', Progress in Human Geography 22/2 (1998) pp. 186-207

${ }^{81}$ D. Newman, 'Borders and Bordering: Towards an Interdisciplinary Dialogue', European Journal of Social Theory 9/2 (2006) pp. 171-186

${ }^{82}$ Newman and Paasi note 80

${ }^{83}$ see D. Wastl-Walter (ed), The Ashgate Research Companion to Border Studies (Farnham, Surrey: Ashgate, 2012 ); T.

Wilson and H. Donnan(eds) A Companion to Border Studies (Chichester: Wiley_Blackwell, 2012)

${ }^{84}$ G. Popescu Bordering and Ordering in the Twenty-first Century: Understanding Borders (Plymouth, Rowman \& Littlefield, 2012)

${ }^{85}$ e.g. P.J. Taylor "The state as container: territoriality in the modern world-system" Progress in Human Geography 18/2 (1994): 151-162

${ }^{86}$ H. Van Houtum, O. Kramsch, and W. Zierhofer W. (eds.) B/ordering Space (Aldershot: Ashgate, 2005).

${ }^{87}$ See C. Brambilla 'Exploring the Critical Potential of the Borderscapes Concept' Geopolitics 20/1(2015): 14-34

${ }^{88}$ ibid; J.W. Scott 'European Politics of Borders, Border Symbolism and Cross-Border Cooperation' in T. Wilson and H. Donnan(eds) A Companion to Border Studies (Chichester: Wiley_Blackwell, 2012)

${ }^{89}$ C. Johnson, R. Jones 'Interventions on Rethinking "the Border"” in Border Studies' Political Geography 30(2011), pp. 61-69

${ }^{90}$ O’Dowd note 5

${ }^{91}$ Novak, note 54, p. 33

${ }^{92}$ Sidaway J., 2011. The Return and Eclipse of Border Studies? Charting Agendas Geopolitics 16/4, pp. 969-976

${ }^{93}$ Newman note 81

${ }^{94}$ P. Kumar Rajaram P. and C. Grundy-Warr Borderscapes. Hidden Geographies and Politics and the Edge of Territory Minneapolis (University of Minnesota Press, 2007); Brambilla note 87

${ }^{95}$ Popescu, note 84

${ }^{96}$ D. Jagetic Andersen, M. Klatt The Border Multiple The Practicing of Borders between Public Policy and Everyday

Life in a Re-scaling Europe (Farnham: Ashgate, 2012)

${ }^{97}$ C. Rumsford Cosmopolitan borders (Palgrave Pivot, 2014)

${ }^{98}$ Mezzadra and Neilson, note 25

${ }^{99}$ N. Parker, and N. Vaughan-Williams 'Lines in the Sand? Towards an Agenda for Critical Border Studies', Geopolitics, 14/3(2009), $582-587$

${ }^{100}$ Johnson and Jones note 89

101 e.g. Paasi, note 79; A. Paasi, E. Prokkola E 'Territorial dynamics, cross-border work and everyday life in the Finnish- Swedish border area' Space and Polity 12(2008): 13-29; Novak, note 4; J. W. Scott, note 88; Perrier Bruslé L.

'The Front and the Line: The Paradox of South American Frontiers Applied to the Bolivian Case' Geopolitics, 12/1(2013): 57-77; K. R. Cox 'Territory, Scale, and Why Capitalism Matters' Territory, Politics, Governance, 1/1(2013), 46-61; authors cited in note 25

102 Thanks to an anonymous reviewer for suggesting this as a point distinguishing this article from recent work engaging with similar themes.

${ }^{103}$ Much resembling the ongoing scalar politics debate in Geography and in Development Studies, see note 76

${ }^{104}$ A. Paasi, 'Place and region: looking through the prism of scale' Progress in Human Geography 28/4 (2004), p. 537

${ }^{105}$ E. Balibar 'What is a border?' in his Politics and the Other Scene (London: Verso. 2002) Ch. 4 pp. 75-8, See also M. Collyer and R. King 'Producing transnational space: International migration and the extra-territorial reach of state power' Progress in Human Geography 39(2005): 185-204

${ }^{106}$ Novak note 4. This is another departure from the framework proposed by Mezzadra and Neilson (see Section 2 , "Development at its Borders"), who seem to consider exclusively borders' productive dimension. See also the implications for progressive politics, sketched in the last section.

${ }^{107}$ Novak note 4

108 A.O. Hirschman 'The Political Economy of Import-Substituting Industrialisation in Latin America' Quarterly Journal of Economics 82(1968), pp.1-32; R. Kiely 'Globalization, Post-Fordism and the Contemporary Context of Development' in International Sociology 13(1998): 95-115

${ }^{109}$ D. Hunt Economic theories of development: an analysis of competing paradigms (New York, Harvester Wheatsheaf, 1989) 
${ }^{110}$ see Saad-Filho and Johnston, note 49

${ }^{111}$ World Bank note 13

112 ibid p. 97

${ }^{113}$ L. O'Dowd 'The Changing Significance of European Borders' Regional \& Federal Studies 12/4(2002)

${ }^{114}$ See Asian Development Bank and World Trade Organisation Mobilizing Aid for Trade: Focus Asia and the Pacific Report and Recommendations Manila (2007) https://www.wto.org/english/tratop_e/devel_e/a4t.../asia_pacific_e.pdf ; African Union Commission, Status of Integration in Africa (2013) www.au.int/en/sites/default/files/SIA\%202013(latest)_En.pdf; in the context of East Asia and Africa, respectively. Accessed 11 April 2015

${ }^{115}$ S. Elden The Birth of Territory (Chicago University Press, 2011)

${ }^{116}$ World Bank Global Economic Prospect (Washington, 2005)

${ }^{117}$ UNDP Integration of Least Developed Countries into the South Asian Free Trade Agreement: A human development perspective (Bangkok, 2011)

118 Sohn, note 15

119 See for example F Söderbaum The political economy of regionalism: the case of southern Africa (New York : Palgrave Macmillan, 2004); B. Dupeyron 'Perspectives on Mercosur borders and border spaces: Implications for border theories' Journal of Borderlands Studies 24(3), 2009; X. Chen As borders bend : transnational spaces on the Pacific rim (Lanham, MD: Rowman \& Littlefield Publishers, 2005)

${ }^{120}$ UN Economic Commission for Africa Industrialising through Trade -Economic Report on Africa Addis Abeba (2015); Asian Development Bank Asian Economic Integration Monitor Manila (2014)

${ }^{121}$ N. Brenner, B. Jessop, M. Jones, G. Macleod (eds) State/Space: a Reader (London: Blackwell, 2003); D. Harvey

'New imperialism: accumulation by dispossession', in L. Panitch and C. Leys, eds, Socialist Register 2004 (London:

Merlin, 2003): 63-87.

${ }^{122}$ Mezzadra and Neilson, note 25, p.206

${ }^{123}$ Ibid., p.242 and Ch. 7 at large

${ }^{124}$ Arnold note 90; M. Casas-Cortes, S. Cobarrubias, J. Pickles 'Riding Routes and Itinerant Borders: Autonomy of Migration and Border Externalization' Antipode (2015) online only

${ }^{125}$ M. Lieven 'Special Economic Zones and Accumulation by Dispossession in India'_Journal of Agrarian Change, 11/ 4(2011), pp. 454-483; P. Sampat Special Economic Zones in India EPW Vol - XLIII No. 28, July 12, (2008)

${ }^{126}$ A. Ong Flexible Citizenship Chapel Hill: Duke University Press (1999)

127 T. Edensor, U. Kothari "Extending networks and mediating brands: stallholder strategies in a Mauritian market." Transactions 31/3(2006): 323-336.

${ }^{128}$ K. Ward Networks of Empire: Forced Migration in the Dutch East India Company (New York: Cambridge University Press, 2009)

${ }^{129}$ F. Söderbaum, I. Taylor 'State, region and space in Africa' in U. Engel; P. Nugent (eds). Africa-Europe Group for Interdisciplinary Studies, Volume 4: Respacing Africa. (Leiden, NLD: Brill, 2010): Ch. 3, pp. 45-70

${ }^{130}$ C. Tornimbeni C. 'Migrant Workers and State Boundaries. Reflections on the Transnational Debate from the perspective of Colonial Past in Mozambique' Lusotopie (2004): 107-120

${ }^{131}$ A. Kaur and I. Metcalfe Mobility, Labour Migration and Border Controls in Asia (Pa;grave, 2006)

${ }^{132}$ Chen note 117

${ }^{133}$ Dupeyron note 90

${ }^{134}$ Paasi note 79

135 O'Dowd note 5

${ }^{136}$ Johnson and Jones note 89

${ }^{137}$ World Development Report 2004. Making Services Work for the Poor (Washington: World Bank, 2004)

${ }^{138}$ World Development Report 1997 The State in a Changing World (Washington: World Bank, 1997)

${ }^{139}$ DFiD webpage http://r4d.dfid.gov.uk/Project/60774/ accessed 20 April 2015

${ }^{140}$ UNDP, Human Development Report 2002. Deepening Democracy in a Fragmented World (New York: UNDP, 2002)

${ }^{141}$ Boudreu note 45; ; I. Dey G. Grappi Beyond Zoning: India's corridors of "Development" and New Frontiers of Capital The South Atlantic Quarterly 114/1(2015): 153-170

${ }^{142}$ N. Akua Anyidoho 'Communities of practice': prospects for theory and action in participatory development Development in Practice 20/3(2010): 318-328

${ }^{143}$ R. Black and H. White Targeting Development: Critical Perspectives on the Millennium Development Goals

(Routledge Studies in Development Economics, 2003)

${ }^{144}$ WDR 2009 note 13

${ }^{145}$ World Development Report 2011 Conflict Security and development (Washington: World Bank, 2011)

${ }^{146}$ USAID/WorldVision Integrating Very Poor Producers into Value Chains Field Guide publication prepared by Dan Norell and Margie Brand for World Vision through the FHI 360-managed FIELD-Support LWA, available at 
https://www.microlinks.org/good-practice-center/value-chain-wiki/overview-value-chain-approach accessed 20 April 2015

${ }^{147}$ R Jones, 'Categories, borders and boundaries', Progress in Human Geography 33, 2008, pp: 174-89

${ }^{148} \mathrm{IMF}$ webpage https://www.imf.org/external/np/exr/facts/prsp.htm accessed 20 April 2015

${ }^{149}$ D. Craig \& D. Porter, 2003, 'Poverty Reduction Strategy Papers: A New Convergence” World Development Vol. 31(1): 53-69

${ }^{150}$ G. Dijkstra, 2005, 'The PRSP approach and the illusion of Improved Aid effectiveness: Lessons from Bolivia, Honduras and Nicaragua' Development Policy Review, 23(4): 443-64

${ }^{151}$ S. Soederberg 'American empire and 'excluded states': the Millennium Challenge Account and the shift to preemptive development' Third World Quarterly 25/2(2004), 279-302

152 A. Escobar Encountering Development (Princeton: Princeton University Press, 1995)

${ }^{153}$ P Cammack 'What the World Bank means by poverty reduction, and why it matters' New Political Economy 9/2(2004), pp.189-211

${ }^{154}$ P. Novak 'Place and Afghan Refugees: a Contribution to Turton' Journal of Refugee Studies 20/4 (2007) pp. 551578

${ }^{155}$ Dijkstra note 150

${ }^{156}$ M. Khan 'Governance during Social Transformations: Challenges for Africa.' New Political Economy, 17/5(2012): pp. $667-675$

G. Harrison, 'Post-Conditionality Politics and Administrative Reform: Reflections on the Cases of Uganda and Tanzania', Development and Change 32(2001), pp. 657-679

${ }^{158}$ F. Golooba-Mutebi and S. Hickey 'Governing Chronic Poverty under Inclusive Liberalism: The Case of the Northern Uganda Social Action Fund' Journal of Development Studies 46/7(2010) 1216-39.

${ }^{159}$ Sinha note 61; D. Kandiyoti, 'Poverty in Transition: An Ethnographic Critique of Household Surveys in Central Asia' in S.Razavi (ed.) Gendered Poverty and Well-Being (Oxford: Blackwell, 2000), pp. 89-113; A.J. Bebbington, D. Mitlin, J. Mogaladi, M. Scurrah and C. Bielich, 'Decentring Poverty, Reworking Government: Social Movements and States in the Government of Poverty', Journal of Development Studies, 46/7(2010), pp.1304-26

${ }^{160}$ T. Faist 'Migrants as transnational development agents: an inquiry into the newest round of the migrationdevelopment nexus' Population Space Place 14(2008): 21-42

${ }^{161}$ S. Lynn Transborder Lives: Indigenous Oaxacans in Mexico, California, and Oregon (Durham: Duke University Press, 2007)

${ }^{162}$ Ong, note 25; see also Mezzadra and Neilson, note 25, Ch 7

${ }^{163}$ See note 34

${ }^{164}$ See also A. Paasi "Academic capitalism and the geopolitics of knowledge" in J. Agnew, A. Secor, V. Mamadouh, J. Sharpe. The Wiley-Blackwell Companion to Political Geography. Oxford: Wiley-Blackwell (forthcoming)

${ }^{165}$ see note 76 